\title{
Self-Contradiction in Faculty's Talk about Writing: Making and Unmaking Autonomous Models of Literacy
}

\author{
Andrea R. Olinger-University of Louisville
} \begin{abstract}
KEYWORDS
autonomous model of literacy; ideological model of literacy; white language habitus; disciplinary writing; WAC/WID; academic literacies; faculty writers; discourse analysis

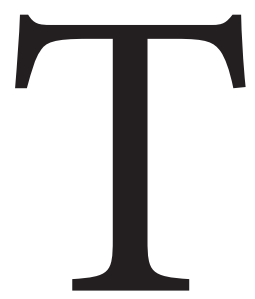

he autonomous model of literacy-what Brian Street (Literacy) has characterized as a "neutral technology that can be detached from specific social contexts" (1) -infiltrates universities, from curricular structures and assessment plans to the students, faculty, and staff who enact them. As scholars in Writing Across the Curriculum/Writing in the Disciplines (WAC/WID), Academic Literacies (ACLITS),
\end{abstract} and related fields have shown, the autonomous model affects where and how writing instruction unfolds in institutions, and it shapes the conceptions and attitudes toward writing of individual faculty and students: who should be responsible for teaching it, what good writing looks like, what writing abilities should be "mastered" at particular stages of schooling (e.g., Boughey; Lea and Street; Rose; Starke-Meyerring).

Street identifies a second, contrasting model, the ideological model of literacy, which sees literacies as anchored in particular social and cultural contexts and molded by epistemologies and power relations. This model explains the situated nature of any literacy practice, including those in academic disciplines; it also accounts for the centuries-old association between academic writing and white Anglo-European epistemologies, which determine how racialized students' language and literacies are typically construed. ${ }^{1}$ As Nelson Flores and Jonathan Rosa argue, "people are positioned as speakers of prestige or non-prestige language varieties based not on what they actually do with language but, rather, how they are heard by the white listening subject" (160). In these ways, the autonomous model of literacy-which includes teachers' beliefs that, in applying universal standards of "academic writing conventions," they are assessing students' texts objectively-operates within the ideological model.

The autonomous model is ideological in an additional sense. Linguist Jef Verschueren defines as ideological "any basic pattern of meaning or frame of interpretation bearing on . . . aspect(s) of social 'reality' ... felt to be commonsensical, and often functioning in a 
normative way" (10). Because these frames are commonsensical, Verschueren explains, they may be "highly immune to experience and observation" (14). As a result, there will likely be disconnections between the ideological frame and outer experience or professed belief/opinion, or between what people say explicitly and what may be inferred from practice.

For the teachers applying a white gaze to racialized students' language use, raciolinguistic ideology that pairs whiteness with appropriateness creates various disconnects, such as between what many profess to value (e.g., students' rights to their own language and racial justice) and what they do in practice (e.g., grade down for deviations from "Standard English" or see deviations where none exist) (e.g., Flores and Rosa; Inoue, Antiracist). And in WAC/WID and ACLITS, researchers have produced compelling evidence of the disjunction between faculty members' assertions (e.g., that good writing is universal and that they are teaching a generic academic essay) and their

\section{"Although they maintained their beliefs in the universal rules, their explanations for the apparent contradictions were complex, shifting, and self-contradictory. Such behavior is compelling evidence that, in individual writers, the autonomous model may be less stable than it at first seems."} own tacit practice (i.e., of discipline-specific literacy practices and of their assessment of student work from a disciplinary, rather than generic academic, lens; e.g., Lancaster; Lea and Street; Thaiss and Zawacki; Wilder). As a feature of any ideological frame, the presence of disconnections between representation and practice could be seen as further evidence of the resilience of the autonomous model. In this article, however, I show how a particular set of theoretical tools, when applied to conversations about such disconnections, in fact reveals the instability of the autonomous model.

In their essay, Flores and Rosa call for shifting language education from an approach that favors appropriateness "toward one that seeks to denaturalize standardized linguistic categories" (168). Thus, instead of "perpetuating the racial status quo," researchers and teachers can "participat[e] in struggles against the ideological processes associated with the white speaking and white listening subject" (168-69). Here, I offer theoretical tools to aid in such denaturalization. Interpretative repertoires, a concept developed by sociologists of scientific knowledge and currently used by critical discursive psychologists, alerts researchers to inconsistency in how interviewees represent their views. Yet in literacy and composition studies scholarship, as in most qualitative studies, participants' inconsistency is usually treated as a problem to be clarified, not as a potential site for analysis. The presence of variability in representations, I posit, shows that the autonomous model's grip on an interviewee is not as strong as a researcher might think.

My claim draws from interviews with two faculty writers. After our initial interviews, I had noticed contradictions between previous comments these faculty writers had made espousing beliefs in particular universal "rules" for good writing and specific linguistic and textual features of the texts they had shared with me. In our follow-up interviews, I asked them to comment on these seeming contradictions. Although they maintained their beliefs in the universal rules, their explanations 
for the apparent contradictions were complex, shifting, and self-contradictory. Such behavior is compelling evidence that, in individual writers, the autonomous model may be less stable than it at first seems. Ultimately, I argue that in conjunction with systemic efforts to dismantle universal notions of "good writing" and white language supremacy, interpretative repertoires and variability can be valuable resources for understanding - and loosening - the thrall of the autonomous model on individual writers.

\section{The Autonomous Text and White Language Supremacy}

Before discussing the concepts of interpretative repertoires and variability and detailing my methods and findings, I first unpack the association between academic writing and whiteness.

Implied in the autonomous model of literacy is an ideal in which texts themselves are autonomous from context. In his 1977 essay in Harvard Educational Review, psychologist David Olson articulates how this view shapes the reading and writing of texts. Abiding by it, one should "write in such a manner that the sentence was an adequate, explicit representation of the meaning, relying on no implicit premises or personal interpretations" (268). This approach "allow[s] a given sentence to have only one interpretation .... [Writers thus needed] to construct sentences for which the meaning was dictated by the lexical and syntactic features of the sentence itself" (270). Olson asserts that this concept originated in Western intellectual traditions, starting with the Greek's invention of a phonemic alphabet and evolving with the development of the printing press, the British essayistic tradition, and the Royal Society of London's policies for scientific prose (269). For instance, the Society's Thomas Sprat, writing in 1667, enjoined scientists to "reject all the amplifications, digressions, and swellings of style: to return back to the primitive purity, and shortness, when men deliver'd so many things, almost in an equal number of words" (2.20.2). ${ }^{2}$

Street renders an extensive critique of the autonomous model of literacy as articulated by Olson and other scholars. For instance, Street points out that the meaning of texts changes over time and space. He further contends that "claims for the objectivity and neutrality" of sentence meaning are "themselves socially constructed conventions, developed within specific social traditions. They should not be taken at face value since they serve more often to privilege the users' own beliefs than as rigorous standards of 'truth"' (4). Ultimately, Street chastises proponents of the autonomous model of literacy, Olson among them, for arguing that their claims-based in their own Anglo-European essayist tradition-apply to literacy in general and for implying that "non-academics in their own culture and members of other cultures, particularly illiterate 'primitives', cannot have the skills of 'objectivity', 'neutrality' and 'logic"' (77). These claims also rest on a problematic distinction between supposedly "subjective, context-dependent" oral language and "objective, context-independent" written language, one that persists today in conversations about "home language" (usually a racialized variety) and "school language," with the former seen as unhelpful to the latter and both erroneously treated as stable, discrete, and homogenous (Flores; Williams-Farrier; Young).

The ideal of the autonomous text directly inspires current understandings of academic writing, synthesized into three principles by Chris Thaiss and Terry Myers Zawacki: "clear evidence in writing 
that the writer(s) have been persistent, open-minded, and disciplined in study" (5); "the dominance of reason over emotion or sensual perception" (5); and "an imagined reader who is coolly rational, reading for information, and intending to formulate a reasoned response" (7). As Asao Inoue points out in his Chair's address at the 2019 Conference on College Composition and Communication, "These judgments, these standards, seem like they're just about language, just about communication, just about preparation for the future, just about good critical thinking and communicating" ("How Do We Language" 358). Yet, of course, given their Anglo-European roots, they are what Inoue calls "white language habitus," whose features he adapts from Catherine Myser's scholarship on whiteness in bioethics. These "discursive and performative dispositions" include "[a focus on] [i]ndividualism, hyperindividualism, self-determination, autonomy, and self-reliance, self-control" and the view that "cognitive capacity is the ability to think rationally, logically, and objectively, with rigor, clarity and consistency valued most" (Antiracist 48-49; see also "Classroom Writing Assessment"). Teachers, usually white but not exclusively so, enact this white racial habitus-part of what Inoue calls white language supremacy ("How Do We Language") — in their assessments of student's written and spoken language. As Flores observes, "whether one is positioned as successfully engaged in academic language is primarily determined by the white listening/reading subject whose perceptions have been shaped by histories of colonialism that continue to frame racialized speakers as coming from communities with linguistic deficiencies that need to be policed and corrected" (24).

Given that whiteness is baked into the construct of academic writing, Flores and Rosa argue that concepts like academic language "must be conceptualized as racialized ideological perceptions rather than objective linguistic categories" (152). The theoretical tools I describe below, as ways to identify and find patterns in writers' contradictory representations, can assist in destabilizing academic writing and, it follows, white language supremacy.

\section{Variability as the Norm: \\ Theoretical Tools from the Sociology of Scientific Knowledge}

The concept of interpretative repertoires originated in a 1984 study of the sociology of scientific knowledge, Nigel Gilbert and Michael Mulkay's Opening Pandora's Box: A Sociological Analysis of Scientists' Discourse. Analyzing interviews with scientists as well as their writings, Gilbert and Mulkay identify two repertoires scientists used when explaining the success or failure of particular theories. The empiricist repertoire "portrays scientists' actions and beliefs as following unproblematically and inescapably from the empirical characteristics of an impersonal natural world" (Gilbert and Mulkay 56); the contingent repertoire operates when "scientists presented their actions and beliefs as heavily dependent on speculative insights, prior intellectual commitments, personal characteristics, indescribable skills, social ties and group membership" (56). They find that in interviews, scientists moved unconsciously and flexibly between repertoires, often describing their own position in the empiricist repertoire and the erroneous positions of others in the contingent. In addition, Gilbert and Mulkay observe that when pushed to resolve the contradictory representations, scientists would argue that the empiricist "truth" would eventually triumph over any contingent influences. 
In a 1985 chapter, “Scientists' Interview Talk: Interviews as a Technique for Revealing Participants' Interpretative Practices," Jonathan Potter and Mulkay demonstrate the utility of identifying apparent contradictions in participants' representations and asking participants about them. This interviewing technique helps researchers "explicate the devices that participants use to resolve inconsistency and reproduce coherent and unproblematic accounts of their social world for particular interactional situations" (267). Critically, Potter and Mulkay do not treat such inconsistencies as a "technical problem" that can be resolved through clarification/reinterpretation from a participant (250). Instead, "given the interpretive flexibility of the resources that respondents use to give accounts of their actions" and the fact that "additional requests for clarification by the interviewer will often generate further apparent contradictions instead of reducing them" (253), such reinterpretations should not be automatically accepted but, instead, treated as an "analytic resource" (257).

Gilbert and Mulkay's interpretative repertoires influenced the fields of discursive psychology and, later, critical discursive psychology (Wiggins). Discursive psychologists examine how psychological issues like attitudes, cognitions, and prejudice are invoked, oriented to, and enacted in interaction (Wiggins). Talk, as a result, is "not treated as an externalisation of underlying thoughts, motivations, memories or attitudes, but as performative of them" (Tileagă and Stokoe 4). Critical discursive psychology developed as an offshoot for researchers interested in how interaction may be influenced by social and cultural ideology (Wiggins).

Interpretative repertoires have been studied in interviews or focus groups about such topics as race and racism (e.g., Wetherell and Potter), gender (e.g., Edley), and marriage (e.g., Lawes). Other fields have also taken them up (see, e.g., Talja in library and information science and McCloskey in nursing). Yet with the exception of Cheryl Geisler's scholarship, the concepts of interpretative repertoires or variability as an analytic resource have not circulated widely in literacy and composition studies.

In her 1994 book, Geisler uses Gilbert and Mulkay's findings to understand the nature of expertise in academic literacy. She points out that scientists possess a "bifurcated practice" (27) between an autonomous notion of texts and a rhetorical one. As writers, they seek to produce autonomous texts by, for instance, making their research seem to emerge inevitably from the literature and the findings from the methods; as readers of others' texts, however, they read skeptically and seek to reconstruct the context. She remarks, "it is only by reserving one language for writing texts about their own work and using another language for reading texts about the work of others that practitioners manage this conflict" (81). She also cites studies showing that this rhetorical view-which can be "informal and tacit" 89)-does not necessarily carry over when one is reading texts outside of one's specialty.

Despite her theoretical interest in scientists' bifurcated discourse practices, Geisler's case studies focus on differences between novices' and experts' composing processes and on the challenges of making rhetorical process knowledge visible in classrooms - not on how experts juggle interpretative repertoires in their talk. For scholars interested in tracing writers' conceptions and attitudes toward writing, however, interpretative repertoires and variability should be essential theoretical tools. 


\section{Methods}

This research derives from a larger IRB-approved study of how groups of academic writersfrom college seniors to faculty members and in such relationships as advisor-advisee and coauthorperceive and practice "writing style" in their disciplines.

With each participant, I conducted an initial literacy history interview, collected examples of their writing (including drafts), and conducted a follow-up text-based interview (Prior, "Tracing"). When I prepared for these follow-up interviews, I reviewed the initial interview transcripts and read the texts they had shared, looking for potential differences between how they represented their writing and specific linguistic and textual features actually present. For instance, as readers will see below, I noticed that Jing Jing had described good writing as text that flowed without relying on transition words, but I found transition words in the piece of writing that she admired, and so I put this apparent contradiction on my list of topics to discuss. ${ }^{3}$

Of my eight focal participants, contradictions between representations and practices emerged in interactions with seven (two undergraduates, two doctoral students, one postdoc, and two faculty). Because of my interest in faculty members' representations of writing, I focus here on the two faculty: Dan Simons, a tenured professor of psychology who is a white American man, and Jing Jing Chang, a tenure-track assistant professor of film studies who is a Chinese Canadian woman. Recognizing that participants have the right to claim authorship and to protect their identity, my consent form allowed them to specify whether they wanted their names or pseudonyms used. Both participants preferred their names. More details about each participant open each case study, below.

When the participant permitted, I supplemented my audio recordings with video because talk is never the only relevant semiotic channel; visual embodied actions like facial expressions and gestures also convey meaning (see Olinger, "Visual"). I videorecorded Jing Jing but not Dan, although he consented. ${ }^{4}$

After producing rough transcripts of the interviews, I identified the excerpts in which, prompted by my questions, Dan and Jing Jing accounted for apparent contradictions between representation and practice. I transcribed these excerpts in finer detail, adapting conventions from conversation analysis (e.g., Sacks, Schegloff, and Jefferson; see Appendix A). A key principle of discourse analysis is that utterances are context dependent and accomplish social actions. As a result, transcribing my questions and backchannels, pauses, and other paralinguistic details (e.g., laughter, intonation) helps me, and readers, understand the co-constructed nature of the interaction (see also Potter and Hepburn). For instance, an interruption from me ("Oh wow. Okay"; see Appendix B/line 19) might be excluded from a transcript with less detail. But this utterance, far from irrelevant, shows me doing work as the interviewer: I am indicating that Dan's explanation is new and surprising to me and that I accept it. ${ }^{5}$

After I produced the more-detailed transcripts, I examined those excerpts for the explanation each writer gave for the contradiction I identified. Noticing that there were multiple different explanations, I kept track of each one.

For the case studies below, I first describe the initial representation and then present the 
apparent contradiction that I had noticed when reviewing the texts I had collected. Next, I narrate the conversation I had with each participant about this apparent contradiction; as I do this, I identify each different account as it emerged. Lastly, I gather the multiple accounts produced by each writer and reflect on what they mean for the autonomous model of literacy.

\section{Dan Simons: "Show, Don't Tell"}

Dan Simons is a cognitive psychologist and tenured full professor who has taught at the University of Illinois at Urbana-Champaign (UIUC) since 2002. With Christopher Chabris, he published The Invisible Gorilla: And Other Ways Our Intuitions Deceive Us (Chabris and Simons), a New York Times bestseller. In 2010, Dan and Christopher blogged for Psychology Today, and they have written many essays for popular media that apply findings in experimental psychology to contemporary issues or review books by science journalists. Dan also developed a writing guide for colleagues and students that is available on his website.

Our initial in-person interview (56 minutes, 10/18/12) covered his experiences with academic and popular science writing, stylistic preferences, collaborations with Chabris, and approach to teaching writing in psychology. We also discussed my feedback on his writing guide, in which he had expressed interest when we had met to discuss his participation in the study. Afterwards, Dan shared multiple drafts of a coauthored article and an op-ed, and I saved copies of his blog posts. The follow-up interview (48 minutes, 3/28/13), which was also in-person, involved text- and discoursebased questions about his writing and student writing containing his comments.

\section{The Initial Representation}

Dan's eight-page writing guide describes "broad principles of effective writing," which include suggestions for an "enticing" opening, "flow," "structure," and revision. These principles are followed by 31 "common mistakes and pet peeves." At the end is a "revision worksheet" containing a distillation of the guide's advice.

One of the 31 "common mistakes and pet peeves" is "Don't say something is interesting without explaining why it is interesting. Better yet, don't say it-show it." This advice is also the last "pro tip" on the sentence-level section of the revision worksheet: "Show it, don't tell it. Give an example to illustrate your point rather than just stating your point. Show that the result is interesting rather than stating that it is."

Several assumptions underlie "show, don't tell." First is the importance of disciplinary evidence, which reflects white language habitus in the preference for logic and rigor. Second is the ideological frame that good writing is universal, which suggests that characteristics of one genre will apply to others. "Show, don't tell" is standard advice in creative writing (e.g., Henkin), and although creative writing is usually considered quite different from academic writing, writing advice for academics may include such guidance (Schimel; Sword). Dan nods to this idea when he writes on his website that the guide covers "scientific writing, but the same principles apply to most non-fiction (including journalism)" (Simons, "Writing and Revising"). 
Dan and I discussed this advice during our initial interview, when we reviewed my feedback on his guide. I remarked that I was wondering if he felt that "show, don't tell" applied to popular science writing, scientific writing, or both, or whether it operated in one type more than the other. I declared that although I understood how this principle functioned in journalism, I was curious how it applied to scientific writing. He replied that it "applies to everything" (line 1; see Appendix $\mathrm{B}$ for the subtitled audio and transcript) and provided an example from a personal statement for graduate school, in which a hypothetical student wrote that they developed "outstanding insights into: clinical populations" (lines 3-4/B ${ }^{6}$ ). Dan remarked that the student shouldn't say they developed "outstanding insights"; instead, they should show that they did. He called this advice a "classic mantra for journalism" (lines 7-9/B).

I then asked him for another example, saying I was "having trouble visualizing" how this advice applied to scientific articles. He responded by raising the issue of using "interestingly" to evaluate data. He implied that "interestingly" isn't necessary because readers will "come to that evaluation" themselves if writers show why the findings are interesting (line 20/B). He added, "And you know I'm guilty of that as well. 'Interestingly' is an easy transition. But if you have to say it's interesting, then it probably isn't to other people unless you (.) explain why, so, just (.) explain it." (lines 22-24/B). Here, he acknowledged the difficulty of always following his advice, and he attributed his inconsistency to willpower, admitting that he has been "guilty" of using an "easy" transition that does not force the writer to explain why something is interesting. Although explaining why might arguably fall under "tell" - it is just a different kind of telling than "interestingly" - this possible contradiction did not come up.

To summarize, Dan upheld the view that "show, don't tell" applies to all good writing and gave two examples of evaluative language ("I developed an outstanding understanding..."; "Interestingly,...") that should be avoided by writers, who would instead display that understanding and that interestingness. At the same time, he mentioned that he has not always followed this advice. Moreover, his comment about the need to explain why something is interesting hints at the flexibility of "show, don't tell" - a quality that recurs in our follow-up interview.

\section{An Apparent Contradiction}

After that interview, I examined the texts that Dan had sent and also began reading his blog. I noticed that one of his scholarly articles was discussed in a blog post (Simons, "Demographics"). Examining the post, I found two instances in which Dan seemed to veer from his advice (See Fig. 1): 
In writing the paper and re-weighting the samples, I discovered something interesting about who responds to these sorts of surveys. Although both could be weighted to a nationally representative sample, the raw demographics of the samples were vastly different. They were roughly comparable on most dimensions (e.g., income, education, region of the country), but their ages differed dramatically.

For me, this figure was eye opening. I wasn't surprised that an online Mechanical Turk sample would be disproportionately younger, and I assumed that phone surveys would oversample the elderly, but I had no idea how extreme that bias would be. What that means is that any national survey conducted by phone is mostly contacting older people. Unless the sample is adequately large, the number of young respondents will be minuscule, meaning that the weighting for those respondents will be huge. If a small survey happened to get a few oddball younger respondents, it could dramatically alter the total estimate.

Fig. 1. Two excerpts from Dan's blog (underlining added).

Immediately after he used the words, Dan explained why the findings are "interesting" and why the figure is "eye-opening." But because he had outlined a rather strict policy to "show, don't tell" where it is preferable to "let [readers] come to that evaluation" (line 20/B) instead of doing the work for them, I wanted to learn his take on his usage. During our follow-up interview five months later, I reminded him of his emphasis on "show, don't tell," showed him the first example from the post, and asked for his "read" on the language (line 13; see Appendix C for the subtitled audio and transcript).

\section{Accounting for the Apparent Contradiction}

As I will show, Dan accounted for the apparent contradiction between representation and practice by arguing that the advice to show, not tell was being applied in the wrong context. Yet in resolving this contradiction, he introduced some new contradictions and redefined "show, don't tell" in the process.

First, he offered a simple explanation: "Um (1.1) Blog style. (1.0) So blog style has more personal (.) narrative uh content to it." (line $14 / \mathrm{C}$ ). He elaborated by saying that he might write "I discovered something" in a blog, but "I would never do that in a journal article." (line 15/C). Yet he then qualified this reason: he stated that he might use language like "we encountered something odd or unusual" in journal articles, although he did not give a reason, and that although he does not like the expression "something interesting," he intentionally uses it in blogs (lines 16-17/C).

Next, he gave another reason besides personal narrative content: "I want to flag what people should pay attention to in that context," (line 21/C). Here, he commits to the value of words that guide the reader through a text and lack a propositional function-thus undermining the autonomous view of texts underpinning much academic writing advice.

When I showed him the second excerpt (See Fig. 1), he accounted for his language use with the 
same reason as before: "So this is- this is basically s- you know blogs are are supposed to be more personal, so (.) I try to give my reactions to things a lot more often," (lines 28-31/C). He explained that many of his posts "are a bit more opinionated and have a bit more of a- you know (1.0) sort of evaluative component to it, and kind of self-evaluative too." (lines 34-37/C). He clarified that he tries to avoid using "interestingly" but sometimes still "need[s] to" use it in blog posts (lines 39-41/C).

I then jumped in with my own defense of his use of "interesting" in the first excerpt: "But it seems to be different because it is (0.2) it is more personal than interestingly." (lines 43-45/C). He agreed and said that because this is a post about a journal article, "here I have to be commenting on something other than just what's in the paper. So (1.0) the the goal is to you know here I kind of put in a little bit about discovery sorts of issues. Right (0.2) whereas I wouldn't talk about (.) the discovery process in a journal article, that's just not what you do." (lines 47-56/C). He added that he does not edit these as much as he does journal articles (line 58/C). I stammered that I didn't mean for my question to come across as a critique (lines 59, 61/C), and he replied, "Yeah, I know but I I might if I were revising it I might change that. ${ }^{\circ}$ I don't know. ${ }^{\circ}$ I mean I edit before I post these things, but not (1.0) not the way I would for a journal article. And I'm the only one who looks at it" (lines 62-66/C).

In saying this, Dan returned to his point that "show, don't tell" applies to journal articles and not blogs, but he acknowledged that he might have deleted that language had he taken more time to edit—or had someone else flagged it. Although Dan justified this apparent contradiction by saying that "show, don't tell" does not apply to blog posts, his comment may indicate that he still feels ambivalent about his use of evaluations like "interesting" and "eye-opening." The desire to follow writing advice universally, to be consistent across genres, seems strong.

After Dan made his point about editing, I interrupted him to return to the writing guide, asking if show, don't tell was relevant in the two examples from his blog post (line 67/C). He replied, "It's more tell." (line 68/C) and qualified his statement: although the post includes the sentence "I found something interesting about who responds," he is "still setting up a mystery here, I haven't told you (.) you know the critical finding yet." (lines 70-73/C). He added, "it's a little more tell" than he usually includes in his posts (line 77/C), "but- if if you look at some of the other ones, I kind of have teasers up at the beginning and then I tell." (lines 78-79/C). Looking across these explanations, "telling" now means not only evaluating the findings ("I found something interesting about...") but also explaining the mystery introduced in the beginning.

Dan then gave a final reason: "There's also the journalism principle that (.) you not not bury the lede. Right. So you're (.) supposed to have something in the first paragraph that pretty much gives away everything you're talking about, so and you have to do that in a blog or nobody reads the whole thing." (lines 83-87/C). Although I had showed him the fourth and sixth paragraphs, he uses this "journalism principle" to support his redefinition of "tell." With this journalism principle, telling happens in the first paragraph.

The Value of Studying These Accounts

Dan's initial representation of good writing was that "show, don't tell" applied to all good 
writing-in essence, supporting the autonomous model of literacy. Yet when accounting for the apparent contradiction by explaining that such markers of affective stance ("interesting," "eyeopening") were appropriate for "blog style," he validated the notion that good writing is contextspecific. This difference alone is enough to reveal cracks in the autonomous model. By looking even more closely at his multiple accounts, however, we can see even more cracks. In this complex series of accounts of his practice-which I as interviewer co-construct, given that I elicited them, accepted them, and offered my own-Dan contends that "show, don't tell" applies everywhere, that it does not apply to blogs, that it is a mantra of journalism but that a basic rule of journalism (don't bury the lede) calls on a writer to tell in the introduction (although the case in point was not actually in the introduction), and that the writing process (with less editing) may account for what must then be seen as a problem.

These cracks in the autonomous model are difficult to notice because of what Gilbert and Mulkay call "conceptual vagueness" (80). Dan suggested that blogs can admit more

"Dan contends that 'show, don't tell' applies everywhere, that it does not apply to blogs, that it is a mantra of journalism but that a basic rule of journalism (don't bury the lede) calls on a writer to tell in the introduction (although the case in point was not actually in the introduction), and that the writing process (with less editing) may account for what must then be seen as a problem." "narrative" features than traditional journal articles, yet in this more narrative genre, "telling" before "showing" fits right in. The vagueness of "telling" resembles the discourse of Gilbert and Mulkay's scientists when they used the contingent repertoire to account for the success or rejection of particular theories. Gilbert and Mulkay note that conceptual vagueness can be

expanded or contracted, withdrawn or supplemented, without creating glaring inconsistencies, to meet the exigencies of each new conversational exchange. They [i.e., vague terms] enable speakers to carry out complex and subtle interpretive work in a way which always leaves them room for further manoeuvre and which always seems to allow the speaker's own scientific views to emerge unscathed. (82)

Indeed, there were no "glaring inconsistencies" during our conversation; it was only upon my scrutiny of what Dan meant by "telling" that contradictions began to emerge. Whereas his initial contradiction was quickly apparent, the additional ones were not immediately visible until after I did more refined transcription and reflection. These inconsistencies reinforce the ideological model of literacy: conventions for good writing are contingent, not universal. Dan is a highly successful, flexible, reflective academic writer, publishing journal articles, popular science writing of various genres, and writing advice. If anyone were to be consistent, perhaps, it would be him. As critical discursive psychologists have shown in various domains, however, these kinds of complex, conflicting accounts are far from unusual. Without these theoretical tools, we would not be able to see the autonomous model crumbling as it is. 


\section{Jing Jing Chang: Good Writing Flows Without Metadiscourse}

Jing Jing Chang is a tenured associate professor of film studies at Wilfred Laurier University (WLU) who moved from China to Canada when she was nine. At our first interview, she was nearing the end of her first year as a tenure-track assistant professor at WLU, in a job she accepted upon graduating from UIUC with a PhD in modern Chinese history and a minor in cinema studies. She had published several book reviews and was working on articles. I met Jing Jing through another participant in my study, a Chinese PhD student at UIUC for whom Jing Jing was a valued writing mentor.

Our initial Skype interview (100 minutes, 5/22/12) included text-based questions about feedback she provided to that UIUC student and questions about her own experiences with academic writing. During our conversation, she mentioned that she admired the writing of an English literature $\mathrm{PhD}$ student, "Adam," a white Canadian man who took her Identity Politics in Film seminar. She connected me with Adam and, with his permission, sent me his final paper with her comments, along with two of her published book reviews and some of her graduate school papers. ${ }^{7}$ After I read her feedback on Adam's paper, I conducted a follow-up Skype interview (80 minutes, 9/12/13).

\section{The Initial Representation}

During our initial interview, Jing Jing articulated the view that a good academic writer is one who transcends seemingly rudimentary supports like transition phrases. She expressed this view when I asked if she noticed any differences in writing style between the English graduate students she now taught in WLU's Department of English and Film Studies and her former graduate-student peers in UIUC's history department. She said that "generally speaking, English students actually write very well" and, laughing, observed that "in fact, I think they can write better than I do." The more courses that history graduate students take, "the more they lose in terms of writing in a very interesting fashion," but English graduate students "write to express themselves" and "want the language, the words, to become beautiful. They want to express an aesthetics." I now provide more detailed quotations from when she began describing, and embodying, these stylistic differences. (See Olinger, “On the Instability," on how gestures can function as metaphors depicting stylistic qualities.)

Jing Jing asserted that writing in history is "stuck" between the social sciences and the humanities (line 1; see Appendix D for the subtitled video and transcript). She explained that history grapples with "big problems" like the humanities do (line 3/D), but its style is similar to that of social science fields like library science, communication studies, sociology, and political science (lines 4-5/D). She then described this social science style as "very boring, like math" (line 6/D), and characterized it by breezing through a typical structure: "step one, step two, step three. Okay this is what I want to prove this is how I'm going to prove it." (lines 8-11/D). As she articulated the stages in this structure, she sliced her flattened hand down through the air in successive steps, enacting the style's cut-and-dried nature (See Fig. 2). Although not apparent in the images, Jing Jing's movements were quick and sharp, demonstrating her negative stance toward this style.

About a minute later, she mentioned Adam, an English PhD student who had taken her seminar 


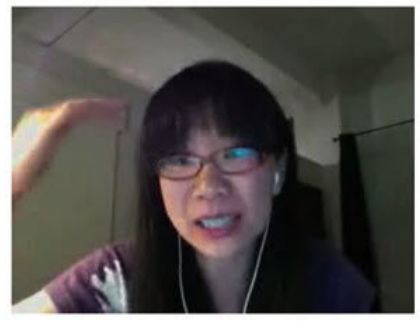

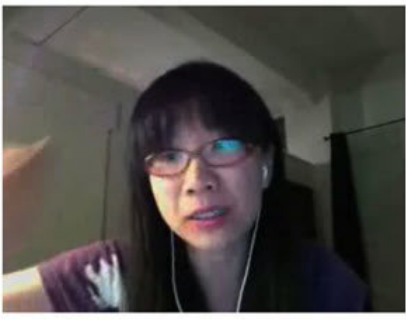

step two,

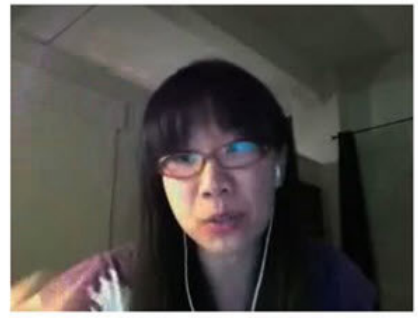

step three.

Fig. 2. Jing Jing slices a flattened hand down in stages to describe a "math" style (lines 8-9/D).

and whose style epitomized this aesthetic sensibility, as he "writes beautifully compared to history students" (line 1; see Appendix E for the subtitled video and transcript) and his style "flows so well" without what she called "arbitrary transitional: phra(h)ses" (lines 8,11/E). While saying that his style "flows so well," her hand moved from a higher plane to a lower one, as earlier, but she smoothly combed her fingers down through the air (see Fig. 3), indicating that she valued this style's "flow" more highly:

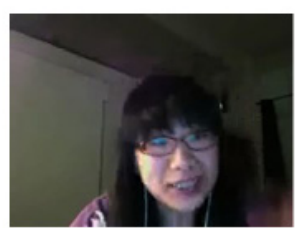

and you know, the style is so:
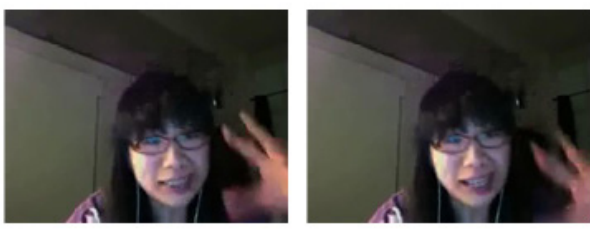

((clicks tongue))
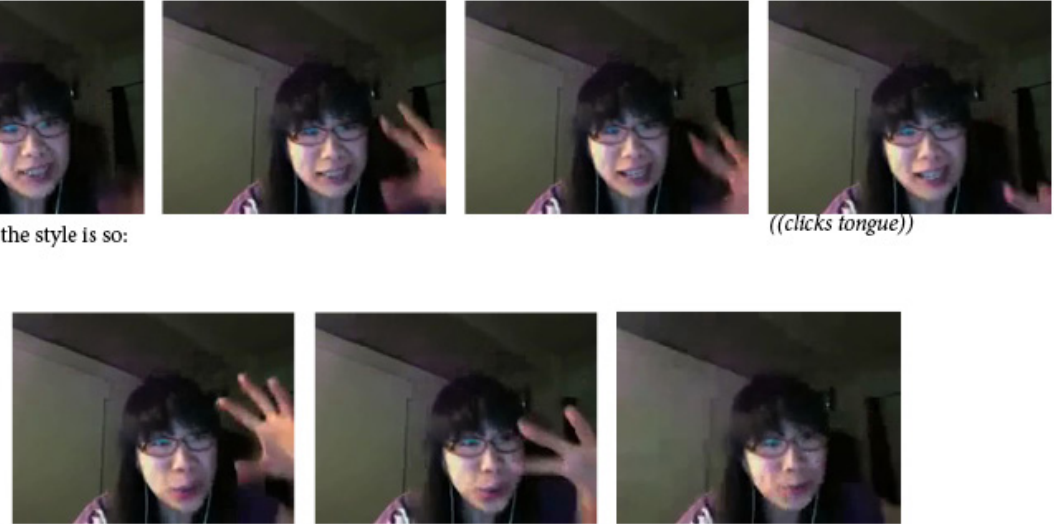

it

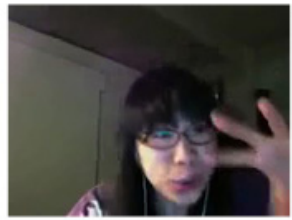

so

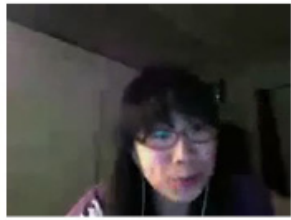

well,
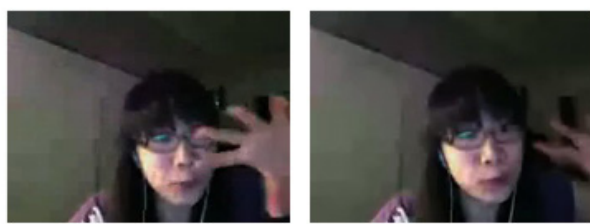

without-

Fig. 3. Jing Jing's gestures describing Adam's flow (lines 5-9E). 
In trying to describe what Adam's writing flows without, she introduced her own habits: "like he wouldn't use like- I I would have this problem I- sometimes I will still use some arbitrary transitional: phra(h)ses to help my paragraphs transition smoothly. In fact the ideas might not flow, but in his writing, he- his ideas flow, (0.8) without those- those phrases," (lines 10-18/E). This pattern-glowing descriptions of his style co-occurring with self-deprecating ruminations on her own-recurs in our follow-up interview.

Jing Jing's views are grounded in the ideal of the autonomous text, which asserts that written language should not require any additional context to be interpreted and which values concision (recall Sprat's "so many things, almost in an equal number of words"). Aligning with this view are critiques of academic writing (e.g., Pinker) that argue that language indicating how readers should interpret content but not directly communicating that content ought to be eliminated. One form of such language is metadiscourse, the "linguistic devices writers employ to shape their arguments to the needs and expectations of their target readers" (Hyland 134). Jing Jing's examples of the problematic style were "interactive resources," one of Hyland's two categories of metadiscourse that "allow the writer to manage the information flow to explicitly establish his or her preferred interpretations" (138). Hyland notes that transitions "mark additive, contrastive, and consequential steps in the discourse, as opposed to the external world" (138) while "frame markers" like "my purpose is to..." and "to conclude" are "references to text boundaries or elements of schematic text structure, including items used to sequence, to label text stages, to announce discourse goals, and to indicate topic shifts" (138). Jing Jing associated metadiscourse with a plodding, step-by-step, abrupt, inelegant style typical of social science fields (and her own writing) and its absence with the flowing, beautiful style typical of English Department writers like Adam.

\section{An Apparent Contradiction}

Jing Jing's representation of Adam's writing, however, differs from what appears in Adam's texts; namely, he uses interactive metadiscourse. When preparing for our follow-up interview about four months later, I recalled her view that Adam did not use transition words, so I searched for them in his seminar paper. In one section, I found three: the words "however," "therefore," and "also." (See Fig. 4). In our follow-up interview, I asked her about them. 
Like Flowers of War, Empire of the Sun breaks down the binary of West/East, but it ultimately does not relinquish the Other, nor give up a view of China as either passive victim or thieving rogue. However, for most of the film, Morris contends, "Spielberg unreels a solipsistic vision of war, involving projection into different positions, rather than any attempt at objective realism" (138). Therefore, the film reveals Orientalism to be representations and not reality. Jamie's personal changes are also connected to the imperial/colonial themes of the film. Jamie's shattered illusion of control and modernization/maturity parallel Britain's decline and America's ascension, respectively. Does the war's shattering of Jamie's illusion merely substitute one colonial power for another though? Is another Orientalist illusion adopted in the end? Hopefully Jamie closing his eyes in his mother's arms signals his embrace of a less discriminatory reality, but the film does not entirely rule out the possibility that Jamie will become just another bureaucrat in the Empire like his father.

Fig. 4. Excerpt from Adam's paper (bold added).

\section{Accounting for the Apparent Contradiction}

As I will show, Jing Jing accounted for the apparent contradiction between representation and practice by arguing that she had simply mischaracterized his writing during our first conversation. Yet in resolving this contradiction, she introduced new ones as she sought to describe what made Adam an exemplary writer.

As we looked at Adam's paper, I pointed out the transition words, and she agreed that they were there (lines 30-37; see Appendix F for the subtitled video and transcript). I responded by providing a reason for the discrepancy between her perceptions of Adam and the reality of his writing: "But they must not have been so noticeable." (line 38/F). Jing Jing agreed and said she didn't notice them because "it's not the same word over and over and over again" (line 39/F). Adam's virtue lies in the fact that he does not rely on the same transition words, not that he uses no transition words.

Jing Jing then contrasted herself and Adam: "I have this problem with writing, it's ver:y bad." (line 40/F). After I asked what she meant, she clarified that her problem was using the same words, namely, the phrase "as such" at the start of a sentence. I responded by laughing and saying, "Okay well that's only one word! .hh ha ha one phrase" (lines 67, 69/F). It appears I thought the issue was lighter than she did. Although she was smiling while I said that, she sounded unconvinced: she replied, "ehhh", exhaled, and shook her head while smiling (line 70/F). My response was again to make light: "that's funny." (line 71/F).

After that exchange, I turned to my final question: what her graduate students struggled with and how Adam was different. She responded that Adam made connections between seemingly opposite ideas, used the theories to understand the films, always had something to say in class, worked harder than other students, and clearly wanted to be there. I then asked whether Adam's language was "more sophisticated or different" from that of other graduate students she had taught. Her reply provided additional representations of Adam's style.

First, she renewed the contrast between herself and Adam, stating, "I hear a voice, I hear his voice. (1.0) Whereas myself included, I I (0.8) am not a good writer." (lines 1-3; see Appendix G for 
the subtitled video and transcript). After a pause, she added, putting her head in her hands, "Um Ohhh (I'm) so: struggling with my writing." (lines 3-5/G). She then said that when she reads his writing, she does not see much language like "According to this writer, he said this, uh there's this (0.8) limitation of this, there's a gap and therefore we should look at this. From this way." (lines $8-12 / G)$-i.e., in technical terms, she does not see evidentials ("According to...") ${ }^{8}$ or explicit statements about one's argument and its place in the larger conversation, which could be described as frame markers (Hyland). While she uttered these paraphrases of hypothetical text, she scooped her voice, enacting the rudimentary quality of each utterance (line $11 / \mathrm{G}$ ).

Jing Jing then clarified that Adam does use this kind of language, but it is not noticeable: "The way he writes it is- there is that, but everything is embedded. It's not- it's not sequential." (lines $12-15 / G)$. She gave another example: he does not use language like "this is what this writer said, okay I disagree because there's something wrong, and this is the new way." (lines 17-20/G). She then evaluated her hypothetical example as "formulaic" (line 24/6), stating that Adam is "willing to even challenge" "the conventional academic style." (line 27/G).

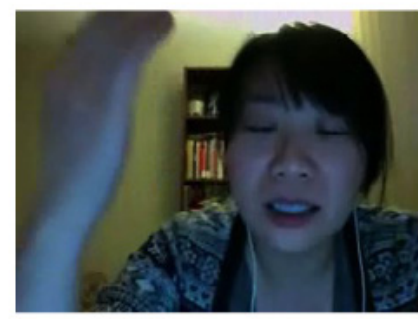

it's

not

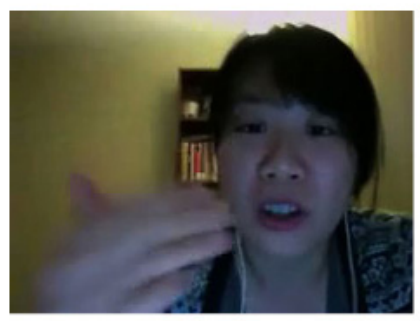

sequential

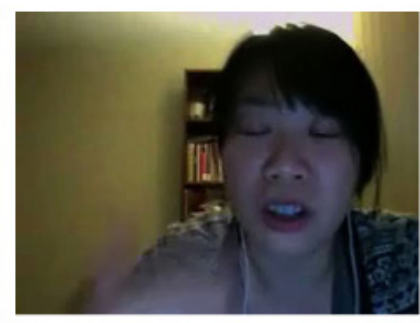

Fig. 5. Jing Jing contrasted Adam's style with step-like gestures (lines 15-16/G).

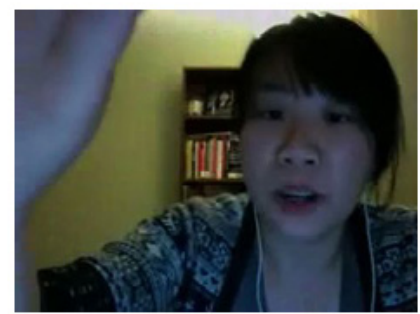

it's not, okay [this] is what this writer said,

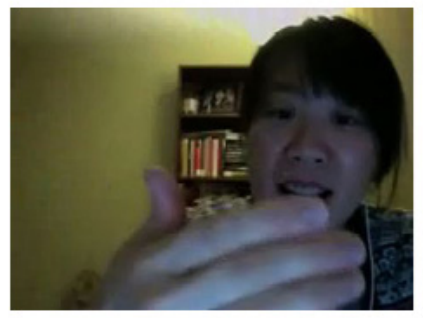

[okay] I disagree because there's something wrong, and [this] is the new way.

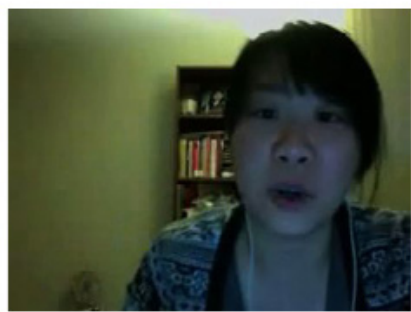

Fig. 6. Jing Jing used step-like gestures while giving examples of formulaic language (lines 17-20/G). 
As she described what Adam did not do, she flattened her hand and stepped it down several levels to depict the "sequential" nature of this kind of formulaic writing (lines 15-16/G; See Figs. 5-6):

Jing Jing initially resolved the seeming contradiction between her representation of Adam's writing and his actual writing by saying that he did not overuse the same transition word. Later in the interview, however, she acknowledged that although he used metadiscourse (not her word), his use was not "sequential" and was instead "embedded"; thus, "You don't hear that." (line 21/G); "You don't see that formula." (line 24/G). Still, when I went back to see if the text was consistent with these representations, I realized that her account had created opportunities for new contradictions. For instance, in the following section of his paper, Adam distinguished his own points from those of Barlow and Said through language like "Barlow explores ...," "By extension, I would argue that ...," "Said never makes clear ...," and “. . . but I would suggest that. ..." (See Fig. 7):

Barlow explores the difficulties of talking about China as a colony, for as many scholars argue, "China was never really colonized" (368). She suggests the need in postcolonial studies to move away from the predominant England/India colonial model (371). By extension, I would argue that Said's Anglo-French-American/Near Eastern model of Orientalism does not precisely apply to China, despite his scattered examples suggesting so. In the chapter, "Orientalism Now," when Said states that "A wide variety of hybrid representations of the Orient now roam the culture" (285), he goes on to mention China and Japan (as well as Indochina, India, and Pakistan). Said never makes clear whether these South and East Asian representations are hybrids of Orientalism, but I would suggest that hybridity is a useful way of thinking about Orientalist representations of China.

Fig. 7. Excerpt from Adam's paper (bold added).

An out-loud reading of those phrases (see bold text in Fig. 7)— "Barlow explores this, By extension I would argue this, Said never makes clear this, I would suggest this"-resembles Jing Jing's stylized version (lines 10-12, 17-21/G), intended to represent what Adam did not do. Although

"What changed, instead, were her representations of the features that demonstrated beautiful writing: Adam didn't use transition words at all, he used them but varied them, or...he used them but embedded them, or he used them in a context where his overall writing had a distinctive and interesting voice."
I identified this passage after our interview, I suspect that asking her about it would not have settled the matter. As Potter and Mulkay show, variability in a participant's responses is rarely a "manageable technical proble $[\mathrm{m}]$ " that can be resolved by "further interpretive work by both parties" (250).

\section{The Value of Studying These Accounts}

Like Dan's explanations for his use of "show, don't tell," Jing Jing's accounts were complex, shifting, and co-constructedas I elicited her accounts, offered my own,

professed to be working on similar issues, and laughed off her assertion that her metadiscourse use 
was problematic. Whereas Dan's accounts invoked, depending on the interactional context, both the autonomous and the ideological model of literacy, Jing Jing's accounts maintained the truth of the autonomous model-specifically, the idea that textual meaning is autonomous and that good writing should therefore flow smoothly without such supports as transition phrases or overuse of the same phrase, code glosses ("as such”), evidentials ("according to...”), or sequential or overly explicit frame markers (e.g., "this is what I want to prove"; “There's a gap and therefore we should look at this"). Yet whereas this idea remained constant, what changed were her representations of the features that demonstrated beautiful writing: Adam did not use transition words at all, he used them but varied them, or-in conceptual vagaries that can be defined by the beholder-he used them but embedded them, or he used them in a context where his overall writing had a distinctive and interesting voice. Again, during the interview, I noticed no inconsistencies (beyond the initial contradiction). It was only upon more-detailed transcription and closer inspection, using the lens of variability from the sociology of scientific knowledge, that the deeper meaning of this interaction was revealed. Although the autonomous model seems to be resilient, the presence of multiple, conflicting accounts belies this apparent strength.

\section{Implications: \\ The Unmaking of the Autonomous Model Of Literacy}

By applying the concepts of interpretative repertoires and of variability as a resource, I gained a close look at the autonomous model as it informed two faculty members' representations of writing during interviews. Although each person produced multiple, shifting explanations, Dan ultimately moved between accounts that good writing is universal and good writing is situated, while Jing Jing maintained that good writing flows without metadiscourse.

Their commitment to the autonomous model, even when shown contradictory evidence, supports research by Laura Wilder on discipline-specific writing in literary studies. Wilder illustrates the effectiveness of a curriculum that explicitly taught the special topoi of literary analysis ${ }^{9}$ in writing-about-literature (WAL) courses designed as gateway courses to the major or as generaleducation courses for non-majors. In her chapter on faculty resistance, she analyzes the reasons of three literature faculty who expressed objections. One, Professor Gregg, was studied separately; Wilder spent a semester observing his WAL course for non-majors in order to see how the topoi naturally informed his teaching. She found an "unacknowledged preference" (63) for the topoi in lectures, discussions, and student papers. After reading a draft of Wilder's analysis, Professor Gregg acknowledged his use of the topoi but rejected their association with disciplinary rhetorical strategies; he preferred to see them, in Wilder's words, as "widely applicable critical-thinking tools" (186), "correct ways to argue" (187) that students could transfer to different contexts. Because of his view of writing and critical thinking as separate from disciplinary knowledge-making, Professor Gregg resisted teaching the topoi more explicitly. To Wilder, his response "suggests that motivating changes in classroom practice may not be accomplished simply by unmasking for professors the ways in which disciplinary rhetorics function" (179). In this case, the influence of the autonomous 
model was stronger than Wilder's intervention.

This research reinforces the presence of contradictions in any study of ideology (e.g., Verschueren). Although our explicit understandings of language and writing do partially shape practices (e.g., Bou Ayash, Calvet), our dispositions often wiggle away, leading to inconsistencies between practices and representations (e.g., Anson, "Pop"; Berkenkotter; Lindenman, et al.). Furthermore, these disconnections are compounded by the fact that our awareness of our own language use is naturally incomplete, a phenomenon documented not only in writing studies scholarship (e.g., Donahue; Nowacek) but also in linguistic anthropology (e.g., Silverstein), sociolinguistics (e.g., Babel; Preston), and psycholinguistics (e.g., Camps and Milian). Even composition and literacy specialists harbor and enact ideologies they themselves might disavow on reflection (e.g., Anson, "Pop"). In my interviews, for instance, I noticed myself promoting views I disagree with (e.g., with an undergraduate who worked with Dan, we laughingly "caught" Dan veering from a writing guide principle in his coauthored book). And, as I mentioned in the introduction, how many of us profess a belief in students' right to their own language but still measure students against a white racial habitus? As writing specialists, we both recognize and resist the pull of the autonomous model—but we cannot expel it entirely. This work requires ongoing self-scrutiny.

Why is the autonomous model of literacy so resilient, despite the glut of evidence that supports the ideological model? So-called universal rules of writing and language, introduced in early schooling (Geisler), become calcified through repeated exposure. Moreover, the fact that "standard language" and "academic writing" are constructs of white language supremacy make them especially inured to disruption. As Flores writes,

Raciolinguistic ideologies were foundational to European colonialism and continue to be used to justify the continued maintenance of white supremacy by suggesting that the roots of racial inequalities lie in the linguistic deficiencies of racialized communities and that the solution to these rational inequalities is to modify their language practices. (24)

Conforming one's practices to an ideological frame can therefore provide a feeling of security: Writers may imagine themselves to be performing membership in particular communities in order to achieve goals, such as getting published and receiving tenure. Janet Giltrow's characterization of meta-genres- "language users' accounts of what they do" (190), whether delivered via handbook, marginalia on student papers, or conversation-acknowledges the safety of these representations. As "widely recognized frames for the writing they direct, shared by readers and writers, collating their perceptions," meta-genres "promis[e], perhaps misleadingly but nevertheless assuringly, an eventual ratification of writers' efforts. Semiotically tied to their contexts of use, accumulating through generations of institutional life, these meta-genres are not lightly surrendered" (199). Safety may be a fiction, but, for these reasons, it is not surprising that the act of presenting writers with apparent contradictions may not be enough to disrupt their understandings about writing or language.

The constancy of Jing Jing's admiration for Adam's writing, despite shifts in what she finds praiseworthy, is a case in point. Across both interviews, reflections on Adam's writing occurred alongside reflections on her own self-perceived flaws. Her steadfast belief that Adam used metadiscourse differently may be rooted in her own lack of confidence in her writing: because she 
struggled with such basics, she may have reasoned, a good writer like him surely did not.

Jing Jing provided more insight into her lack of confidence at other points during our follow-up interview. For instance, she declared that in the first year and a half of her job, "I was too proud, I did not even show my work to anyone, of course I got rejected [from journals]. I was just so afraid, maybe I felt ashamed of my work, and I had to relearn everything. It's been so long since my dissertation, and it's been a struggle" (Interview, 9/12/13). She also remarked that the stakes-publishing enough to get tenure while managing a heavy teaching load - are high. It therefore may feel risky to abandon familiar notions of good writing. Her experience of having to "relearn everything" since her dissertation and her struggle to make time for research have arguably attached considerable anxiety to this figure of a "good writer" Adam represents.

The above analyses reveal the invisible labor involved in upholding the autonomous model of literacy ${ }^{10}$. Perceived qualities of "good writing" are not emanations from the text but are coconstructions, molded by the values of the listener/interlocutor or reader (Olinger, "Sociocultural"). And given that all perceptions of language are shaped by raciolinguistic ideologies (Flores and Rosa; Inoue, Antiracist), they may be entirely disconnected from the text. Flores and Rosa give examples of racialized students being heard by teachers as uttering nonstandard speech even when they are producing standardized forms; in a similar way, Jing Jing "read" into Adam's writing qualities that were directly contradicted by textual evidence. In both cases, what is "read" are not linguistic features but, more broadly, an assemblage of embodied semiotic features-such as apparent skin color or proximity to whiteness, clothing style, or posture (e.g., Agha; Rosa and Flores). Jing Jing praised Adam's thinking, work ethic, and class participation; these attributes may inform what she sees when she reads his writing, even if the text does not back her perception. ${ }^{11}$ Furthermore, Adam's position as a white Canadian English speaker and writer may undergird these judgments.

Given the harm these representations can sow, college writing teachers must come to terms with the racism that underlies their judgments. ${ }^{12}$ Of course, we cannot stop at the individual level. Synthesizing language ideology scholarship and critical race theory, Mark Lewis warns sociolinguists not to focus their activism solely on correcting erroneous views through the presentation of linguistic evidence-a practice similar to thinking that racism can be solved simply by changing the beliefs of individuals. Sociolinguists who seek social change, he argues, need to recognize and target the material structures in which these representations of language are embedded.

Activism directed at the structures of white language supremacy has involved addressing admissions and placement testing and revising curricula, learning outcomes, and classroom-based assessments (e.g., Inoue, Antiracist, "Classroom Writing Assessment”; Kareem; Perryman-Clark and Craig). Recent initiatives in WAC/WID have also focused on institutional structures (e.g., Cox, Galin, and Melzer), ${ }^{13}$ and the University of Minnesota's Writing-Enriched Curriculum initiative demonstrates an institutional approach that uses regular department meetings to unearth and trouble individual faculty's assumptions (Flash). Yet WAC/WID has long neglected issues of racism and white language supremacy (Anson, "Black Holes"; Kareem; Poe). One exciting development is Jamila Kareem's “CSP-WAC": a culturally sustaining WAC pedagogy that "treats the literate cultural perspectives from communities of color or with the same respect, circulation, and criticism typically 
reserved for the mainstream Euro-Western cultural practices of the academy" (301). CSP-WAC refines the approach of Writing Across Communities (Kells) through an emphasis on sustaining raciolinguistically marginalized students' literate practices.

How powerful are the theoretical tools of interpretative repertoires and variability, really? Because many people will not be convinced by evidence, our attention as scholars must be directed at dismantling systemic barriers. And even as some will be convinced by evidence, we nevertheless must target institutional structures, the seedbed of linguistic racism. Yet when combined with systemic efforts, work at an individual level is not in vain: In exposing the instability of individuals' representations of writing, interpretative repertoires and variability reveal cracks in the autonomous model of literacy that would not have emerged otherwise. May these tools, therefore, be more regularly enlisted and discussed-with writers, teachers, research participants, and others we might collaborate with - to split open altogether the false construct of "good writing." 14,15 


\section{APPENDIX A:TRANSCRIPT CONVENTIONS}

\begin{tabular}{|c|c|}
\hline Symbol & Gloss \\
\hline $\begin{array}{l}\text { D: [gives away everything] }[[\text { you're talking }]] \text { about, } \\
\text { A: }[\mathrm{Mmm} \text { hmmm }] \\
\mathrm{J}: \underline{\text { step }}[[\text { honmmmm },]] \underline{\text { step }}[[\text { two, }]] \text { step }[[\text { three. }]] \\
[[\text { (steps flat hand down a level })]]\end{array}$ & $\begin{array}{l}\text { Brackets (single, double, or } \\
\text { triple) indicate overlap. }\end{array}$ \\
\hline $\begin{array}{l}\text { D: kind of um= } \\
\text { A: =would }\end{array}$ & $\begin{array}{l}\text { Equals signs indicate the } \\
\text { utterances follow one } \\
\text { another without a pause. }\end{array}$ \\
\hline (steps flat hand down a level) & $\begin{array}{l}\text { Italicized text within } \\
\text { parentheses indicate } \\
\text { embodied actions like } \\
\text { gestures }\end{array}$ \\
\hline they'll (draw the right idea) & $\begin{array}{c}\text { Single parentheses indicate } \\
\text { the transcriber's best guess } \\
\text { at what was said. }\end{array}$ \\
\hline$(2.0)$ & $\begin{array}{l}\text { Numbers in parentheses } \\
\text { indicate the duration of a } \\
\text { pause in seconds. }\end{array}$ \\
\hline (.) & $\begin{array}{l}\text { A period within parentheses } \\
\text { indicates a micropause, } \\
\text { about one-tenth of a second. }\end{array}$ \\
\hline${ }^{\circ}$ Right $^{\circ}$ & $\begin{array}{c}\text { Degree signs around an } \\
\text { utterance indicate that it } \\
\text { was spoken at a lower } \\
\text { volume. }\end{array}$ \\
\hline I had no idea how $>$ blah blah blah blah blah $<$ & $\begin{array}{l}\text { Greater-than and less-than } \\
\text { signs around an utterance } \\
\text { indicate that the utterance } \\
\text { was rushed compared to the } \\
\text { surrounding talk. }\end{array}$ \\
\hline And here too for eh- I like this example too & $\begin{array}{l}\text { A hyphen indicates cut-off } \\
\text { speech. }\end{array}$ \\
\hline
\end{tabular}




\begin{tabular}{|c|c|}
\hline Symbol & Gloss \\
\hline the style is so: & $\begin{array}{l}\text { One or more colons indicate } \\
\text { a sound stretch-the more } \\
\text { colons, the more prolonged } \\
\text { the sound. }\end{array}$ \\
\hline Right? & $\begin{array}{l}\text { A question mark indicates } \\
\text { rising intonation, not } \\
\text { necessarily a question. }\end{array}$ \\
\hline Political science. & $\begin{array}{l}\text { A period indicates falling } \\
\text { intonation. }\end{array}$ \\
\hline you have emphasized kind of "show don't tell", & $\begin{array}{l}\text { A comma indicates rising- } \\
\text { falling ("continuing") } \\
\text { intonation. }\end{array}$ \\
\hline$\underline{B l o g}$ style & $\begin{array}{c}\text { Underlining indicates a } \\
\text { stressed syllable. }\end{array}$ \\
\hline hah, heh, hih & $\begin{array}{l}\text { Hah, heh, and hih mark } \\
\text { laughter. }\end{array}$ \\
\hline What are the $\mathrm{sa}(\mathrm{h})$ me words that you $\mathrm{u}(\mathrm{h}) \mathrm{se}$. & $\begin{array}{l}\text { H's within parentheses } \\
\text { mark utterances infiltrated } \\
\text { by laughter. }\end{array}$ \\
\hline.$h h$ & $\begin{array}{l}\text { A period plus one or more } \\
\text { h's indicate that the speaker } \\
\text { has inhaled. The more h's, } \\
\text { the louder and longer the in- } \\
\text { breath. }\end{array}$ \\
\hline hh & $\begin{array}{l}\text { One or more h's indicate } \\
\text { that the speaker has } \\
\text { exhaled. The more h's, the } \\
\text { louder and longer the out- } \\
\text { breath. }\end{array}$ \\
\hline
\end{tabular}




\section{APPENDIX B: DAN'S EXPLANATION OF “SHOW, DON'T TELL” (INITIAL INTERVIEW, 10/18/12)}

Subtitled Audio: https://vimeo.com/492250886

$01 \mathrm{D}:$ I think this applies to everything. Right, so, you kn- this i- this is the one where- I'm 02 now reading their personal statements for grad school, right. A:nd, they'll say things

03 li:ke, uh: I developed an outstanding underst- ya know- outstanding insights into:

04 clinical populations. (1.0) Don't say: [you've] developed outstand-, show that you

$05 \mathrm{~A}$ : [hahaha]

06 D: have. Right. So, I mean- but that's not talking about findings, it's talking about (.) your [abilities] But it applies everywhere. That's- that's just kind of the classic

08 A: $\quad[\mathrm{R}$ ig h t]

$09 \mathrm{D}$ : [[mantra for journalism, right, so]]

10 A: [[Right. (And) I guess for- thinking about-]] when I was thinking about a scientific

12 D: Mmhm

13 A: And so I really wanted to see an example of-

14 D: Yeah

15 A: of what that looked like, what did it mean you- would s- you would use the data to shto show:, or

17 D: I (.) I think it's more in the evaluation part. Right, so (.) the phrase "interestingly"

18 [ (2.0) ]

19 A: [Oh wow. Okay]

20 D: That's an evaluative state[ment.] Let them come to that evaluation. Show it, and

22 D: they'll (draw the right idea). And you know I'm guilty of that as well. "Interestingly" is an easy transition. But if you have to say it's interesting, then it probably isn't to other people unless you [ (.) ] explain why, so, just (.) explain it.

26: A: O:kay. That mak-=

$27 \mathrm{D}: \quad=$ Yeah $=$

28 A: =that-

29 D: [(that's- I think that's a)]

30 A: [(Now/No) I think that makes] clearer sense

31 D: It's more in the evaluation end of it than in the presentation of data.

32 A: Tch okay, okay. 


\section{APPENDIX C: DAN'S ACCOUNT FOR THE APPARENT \\ CONTRADICTION (FOLLOW-UP INTERVIEW, 3/28/13) \\ Subtitled Audio: https://vimeo.com/492251966}

01 A: It was [really cool to see] your blog post of the- of the article

$02 \mathrm{D}: \quad$ [that blog post huh] $\mathrm{Mm} \mathrm{hm}$

03 A: and to compare them and I know: you: have emphasized kind of "show don't tell,"

$04 \mathrm{D}: \mathrm{Mm} \mathrm{hm}$

05 A: And so I wondered if you could talk through (.) what you think about

$06 \quad[(1.0)]$

$07 \mathrm{D}: \quad[\mathrm{Mm}]$

08 A: um for example $>$ I discovered something interesting (1.0) Buh da da da da da da< so you

$10 \mathrm{D}: \mathrm{Mm} \mathrm{hm}$

11 A: um you say what's interesting, but you I I know that you've [(.)] kind of pointed

12 D:

13 A: this out so how- what's your read (0.5) on this.

[Right]

14 D: Um (1.1) Blog style. (1.0) So blog style has more personal (.) narrative uh content to it. So you $>$ can say I discovered something, $<$ I would never do that in a journal article. Right. Um, you might say we- you know, you might say we encountered something odd $[()$.$] or unusual, right. Um, I normally don't like saying something interesting, but$ [Hm]

20 A: ${ }^{\circ}$ Right $^{\circ}$

21 D: because it's- I want to flag what people should pay attention to in that context,

$22 \mathrm{~A}:{ }^{\circ} \mathrm{Mmm}^{\circ}$

23 D: um [(2.0)]

24 A: $\quad\left[{ }^{\circ} \mathrm{Hm}^{\circ}\right](2.0)$ And here too for eh-

25 D: Yeah

26 A: I like this example too- I wasn't surprised that $>$ dih dih $\operatorname{dih}<$ but I had no: idea how $>$ blah blah [blah blah blah. $<$ ]

[Mm hm Right.] So this is- this is basically s- you know blogs are are supposed to be more personal, so (.) I try to give my reactions to [things] a lot more

32 A: ${ }^{\circ} \mathrm{Mmm}^{\circ}$

33 D: so I mean if you if you look through most of the blog posts I have, (1.0) um they have a l- some don't, (.) but (.) a lot of them are a bit more opinionated [and] have a bit

more of a- you know (1.0) sort of evaluative component to it, and kind of self-

38 A: ${ }^{\circ} \mathrm{Mmm}$ okay $^{\mathrm{o}}$

39 D: I wouldn't- I wouldn't- I try and avoid saying you know interestingly (1.0) um at least now I used to. I kind of s- that's kind of a dumb thing to do. So I've kind of worked

41 away from that, but (.) on blog posts you still [kind of] need to every now and then.

43 A: But it seems to be different because it is $(0.2)$ it is more personal than 
44 D: Yeah,

45 A: interestingly.

46 D: And this was kind of I I mean- since- the paper speaks for itself as a- as an empirical

47 piece, so here I have to be commenting on something other than just what's in the

48 paper.

49 A: ${ }^{\circ} \mathrm{Mm}\left[\mathrm{hm}^{\circ}\right]$

50 D: $\quad$ [So] (1.0) the the goal is to you know here I kind of put in a little bit about 51 discovery sorts of issues.

52 A: ${ }^{\circ} \mathrm{Mm}\left[\mathrm{hm}^{\circ}\right]$

53 D: $\quad$ Right] (0.2) whereas I wouldn't talk about (.) the discovery process in a journal 54 article,

55 A: ${ }^{\circ} \mathrm{Hmm}\left[\mathrm{mm}^{\circ}\right]$

56 D: $\quad$ [that's] just not what you do.

57 A: Right:: (3.0) [ $\left.{ }^{\circ} \mathrm{Kay}^{\circ}\right]$

58 D: But (1.8) And you know, I don't edit these as much as I do a journal article(h) hh

59 A: Oh I I I

60 D: Yeah.

61 A: And I wasn't (.) pointing that [out (as a critique)]

$62 \mathrm{D}$

63 change that. ${ }^{\circ}$ I don't know. ${ }^{\circ}$

[Yeah, I know but] I I might if I were revising it I might

64 A: ${ }^{\circ} \mathrm{Okay}^{\mathrm{o}}$

65 D: I mean I edit before I post these things, but not (1.0) not the way I would for a journal

66 article. And I'm the only one who looks at it and- (that's)

67 A: Would you fit this under the "show don't tell" uh (1.0) kind of um=

$68 \mathrm{D}: \quad$ [=It's more] tell. Um I mean wh- this is- you know, I probab- (2.8) when I try I still

69 A: [=(would)]

$70 \mathrm{D}$ : try and kind of set up (.) "I found something interesting about who responds," but I'm

71 still setting up a mystery [here,] I haven't told you [[(.)]] you know the critical

72 A: $\quad\left[{ }^{\circ} \mathrm{Mmm}^{\circ}\right]$

73 D: finding yet. Right, (.) Um (6.0) Yeah. (2.0)

$74 \mathrm{~A}:{ }^{\circ} \mathrm{Mm}\left[\mathrm{kay}^{\circ}\right]$

75 D: $\quad$ So] I mean hh it it's kind of in between,

76 A: Yeah,

77 D: It's a little more- it's a little more tell than I typically do in this sort of context, but-

78 if if you look at some of the other ones, I kind of have teasers up at the beginning

$79 \quad$ [and then I tell.] hh

80 A: $\quad\left[{ }^{\circ} \mathrm{Mmmmmmm}^{\circ}\right] \quad{ }^{\circ} \mathrm{Hmm}^{\circ}$

81 D: Um

82 A: ${ }^{\circ} \mathrm{Hm} \mathrm{kay}^{\mathrm{o}}$

83 D: There's also the journalism principle that (.) you not not bury the lede. Right. So

84 you're (.) supposed to have something in the first paragraph that pretty much

85 [gives away everything] [[you're talking]] about,

$86 \mathrm{~A}: \quad[\mathrm{Mmm} \mathrm{hmmm}] \quad[[\mathrm{hmmmmm}]]$ huh

$87 \mathrm{D}$ : so and you have to do that in a blog or nobody reads the whole thing. 


\section{APPENDIX D: JING JING'S CHARACTERIZATION OF \\ WRITING STYLE IN HISTORY (INITIAL INTERVIEW, 5/22/12) Subtitled Video: https://vimeo.com/492252346}

$01 \mathrm{~J}$ : So history is [stuck,] I think [stuck] in between (.) the social sciences and humanities.(.)

Big problems, the big problems is humanities, but the style itself is more still social science style. Right? Like like library science or- or communication studies verysociology, right? Political science. If you read sociology, a work in sociology, political science, they're very boring, like math, okay >bl- blah [blah blah okay] step [[one,]] step [[two,]] step [[three.]] Okay this is what I want to [[[[prove]]] 


\section{APPENDIX E: JING JING'S DESCRIPTION OF ADAM'S WRITING STYLE (INITIAL INTERVIEW, 5/22/12)}

Subtitled Video: https://vimeo.com/492252624

$01 \mathrm{~J}$ : Well from my perspective he he he writes beautifully compared to history students

02 A: Mm::

$03 \mathrm{~J}$ : um so it's

$04 \mathrm{~A}: \mathrm{hm}$

$05 \mathrm{~J}: \quad$ it's loading loading [and and] you know, the style is [[so: (.)]]

06 A:

$07 \mathrm{~J}$ :

08

09

14

$15 \mathrm{~A}:[\mathrm{Mm}]$

(clicks tongue) it [flows] so [well,] without (1.0)

[(Do you know what)]

[[(combs hand down through air $)]]$

$16 \mathrm{~J}$ : [but] in his writing, he- his ideas flow, (0.8) without those-

$17 \mathrm{~A}:$ (clicks tongue)

$18 \mathrm{~J}$ : those phrases,

19 A: Mm::

$20 \mathrm{~J}$ : um: yeah.

Note: Her comment that "it's loading" (line 5) refers to the syllabus file she is trying to open. 


\section{APPENDIX F: JING JING'S ACCOUNT FOR THE APPARENT CONTRADICTION (FOLLOW-UP INTERVIEW, 9/12/13) \\ Subtitled Video: https://vimeo.com/492252942}

$01 \mathrm{~A}:$ I remember the last time we spoke you talked about uh transition words, .hh and [how]

$02 \mathrm{~J}$ :

03 A: you (0.2) um tch in your own writing you really tried to: get rid of them?

04 and and [craft] (.) craft transitions without relying on those [[words,]] and you- I think

$05 \mathrm{~J}:$ [yes] [[yes]]

$06 \mathrm{~A}$ : you mentioned that he- (1.0) he was- he did a good job of that?

$07 \mathrm{~J}$ : yes I think so

08 A: um [and so I] I was um-

$09 \mathrm{~J}: \quad$ [I remember.]

$10 \mathrm{~A}$ : so I was [[looking out for transition words in this paper]]

$11][(\operatorname{smiling}$ intonation $)]]$

12 [and um]

$13 \mathrm{~J}: \quad$ [were there?]

14 A: hih hih .hh

$15 \mathrm{~J}$ : were there?

$16 \mathrm{~A}$ : there were!

$17 \mathrm{~J}: \quad$ (starts smiling)

$18 \mathrm{~A}:$ and I think maybe especially on page thirteen (1.0)

$19 \mathrm{~J}$ : ahh

20 A: hih hih hih [hih hih] hhh um (1.0)

$21 \mathrm{~J}$ [ha ha ha]

$22 \mathrm{~J}: \quad$ yes

23 A: see I- I mean I- I'm trying to work on that too in my own writing, and so I'm interested 24 in- in these- (1.0) in transi[tion words]

$25 \mathrm{~J}$ : [oh yeah yeah] I see that yeah

$26 \mathrm{~A}:$ um the [[the first paragraph]]

$27 \mathrm{~J}: \quad[[$ oh yes yes yes]]

$28 \mathrm{~A}:$ on [page thirteen so I just thought [[[that]]] was um]

$29 \quad[(\operatorname{siniling}$ intonation $) \quad]$

$30 \mathrm{~J}$ : [[[yeah]]] oh yes (1.0) oh yeah (2.0) yes I

31 see that. Yes I see. There's a lot

$32 \mathrm{~A}: \mathrm{hh}$

$33 \mathrm{~J}$ : In fact.

34 A: .hhh

$35 \mathrm{~J}$ : yeah yeah yeah

36 A: .hh

$37 \mathrm{~J}$ : yeah (.) yeah

38 A: But they must have not been so noticeable.

$39 \mathrm{~J}$ : .h yes because it's not the same word over and over and over again (3.0)

40 I have this problem with writing, it's ver:y bad. (1.0)

41 A: of using the same words?

$42 \mathrm{~J}$ : [uh huh!] Using the same words

$43 \quad[($ nods $)]$

44 A: hih hih .hhh 
$45 \mathrm{~J}: \quad$ It's terrible.

46 A: What are the sa(h)me words that you $\mathrm{u}(\mathrm{h}) \mathrm{se}$.

$47 \mathrm{~J}: \quad$ hh (1.0) uh As [such (0.8)

$48 \quad$ [(smiling $)]$

49 A: ha ha ha ha ha really!

$50 \mathrm{~J}: \quad[\mathrm{mm} \mathrm{hm}]$

$51 \quad$ [(nods, smiling $)]$

52 A: .hhh hah!

$53 \mathrm{~J}: \quad$ ah (0.8) Basically that's it.

54 A: A(h)s su(h)ch! [Tha(h)t's] the(h)

$55 \mathrm{~J}: \quad[\mathrm{mm} \mathrm{hm}]$

$56 \mathrm{~J}: \quad[($ nods, smiling $)]$

$57 \mathrm{~J}: \quad \mathrm{mm} \mathrm{hm}[$ shakes her head, smiling)

58 A: I can't even think of the- the context of-

$59 \mathrm{~J}: \quad$ As such,

$60 \quad$ [(smiling $)]$

61 A: Oh oh: As su:ch, [[duh::: ]

$62 \mathrm{~J}:$

$63 \mathrm{duh}<$

64 A: In this way, [it's sorta a- kinda a- similar okay]

$65 \mathrm{~J}: \quad[($ nods, smiling $) \quad][$ hh

$66 \mathrm{~J}$ :

67 A: Ha ha .hh Okay well that's only one word!

[[(smiling, shaking her head $)]$

$68 \mathrm{~J}: \quad$ [hhh] [hhh (smiling, looks away)]

69 A: [.hh] ha ha [one phrase

$70 \mathrm{~J}: \quad$ ehhh hh (shakes her head, smiling)

71 A: that's funny. 


\section{APPENDIX G: JING JING'S ADDITIONAL DESCRIPTION OF ADAM'S STYLE (FOLLOW-UP INTERVIEW, 9/12/13)}

Subtitled Video: https://vimeo.com/492253171

$01 \mathrm{~J}$ : I hear, I I see in his in his [writing,] I hear a voice, I hear his voice. (1.0) Whereas

02

03 [(draws a finger through the air like a pencil)]

myself included, I I (0.8) am not a good writer. (1.0) Um [[Ohhh]]

[[(puts her head in her hands $)]]$

(I'm) so: struggling with my [writing.] But I- I I I hear I see that he- somehow the first [.hhh]

impression I got when I read that paper or in his class in his other writing (1.0) he I- I

don't see:, I don't hear: um tch oh (1.0) I don't see so much of this. [Such as]

[(makes air-quotes)]

According to this [writer,] he said [this,] uh there's this (0.8) limitation of this,

[(scoops voice to create simplistic air)]

there's a gap and therefore we should look at this. From this way. The way he writes

it is- there is that, but [everything is embedded.]

[(circles hand around face)]

It's not- it's not [[sequential.]] .hh (1.0) uh [[The- the the w- the]] um tch $[[($ steps flat hand down several levels $)]]$

It's not, okay [this] is what this writer said, [okay] I disagree because [there's] [(steps flat hand down a level)]

something wrong, and [[this]] is the new way.

$$
\text { [[(steps flat hand down a level) }]]
$$

[This] is the new pers[[pective.]] You don't hear that. You don't hear [(slices hand for emphasis)]

[[Mmm]

that (2.0) mm formulaic way. You don't see that formula. It's it's it's something different. It's a new-it's a confidence that I see. In his writing. [That] That he's [Hmm]

willing to even challenge the (2.0) uh (1.8) the the conventional academic style. (2.0) uh (1.0) Think that's (1.0) that's what I felt. 


\section{NOTES}

${ }^{1}$ I follow Flores and Rosa and Rosa in using "racialized students" instead of "students of color" to emphasize the social processes through which race is constructed.

${ }^{2}$ See Walters for a more nuanced reading of the Royal Society's theories and practices of language and Street (39-40) for a biting critique of Olson's point.

${ }^{3}$ If I had multiple drafts of the same text, I developed discourse-based interview questions that queried reasons for particular changes (Odell, Goswami, and Herrington; Prior, "Tracing”). For the texts examined in this article, however, I did not possess multiple drafts. I also traced participants' interactions with more novice academic writers, but that, too, is not the focus of this article.

${ }^{4}$ The reason was, to be candid, that, at the time of the interview, I was feeling overwhelmed and did not want to bother setting up the camera. For more on the vagaries of collecting usable video data, see Olinger, "Visual," 11.

${ }^{5}$ For conversation analytic work on "oh" and other response tokens, see Gardner, Heritage, and Wilkinson and Kitzinger.

${ }^{6}$ Letters after line numbers identify the appropriate appendix.

${ }^{7}$ Adam became a study participant.

${ }^{8}$ Evidentials "indicate the source of textual information which originates outside the current text" (Hyland 139).

${ }^{9}$ Examples include appearance/reality and paradox.

${ }^{10}$ This work was at first barely noticeable to me as an interviewer. For several years after conducting the interviews - in multiple presentations-my analysis of these moments would stop at identifying contradictions between representation and practice and asserting expert writers' limits of awareness. It was only after I looked more closely, beyond the writers' initial responses, that I began to notice the different accounts that unspooled.

${ }^{11}$ See also Paul Prior's analysis of how Dr. Kohl "read into" his students' texts (Writing/ Disciplinarity 86).

${ }^{12}$ Inoue acknowledges that because teachers may have trouble shedding their preference for students who enact a white language habitus, structural changes-even in one's classroom-are needed: "I'm not saying we have to change our perspectives, soften our hearts. Our hearts are not the problem. In fact, I'm actually saying the opposite, that we cannot change our biases in judging so easily, and that your perspectives that you've cultivated over your lifetime are not the key to making a more just society, classroom, pedagogy, or grading practice. The key is changing the structures, cutting the steel bars, altering the ecology, in which your biases function in your classrooms and communities" ("How Do We Language" 364).

13 Ursula Wingate remarks that ACLITS research has tended to focus on "individual understandings and applications . . . in confined contexts" (186). "When it comes to changes in institution-wide policies and practices that would result in transforming the experience of whole student populations," she writes, "Academic Literacies has had less impact" (ibid.).

${ }^{14}$ Potter and Mulkay as well as Margaret Wetherell and Potter provide useful guidance for 
researchers seeking to analyze interpretative repertoires and understand the patterns behind seeming inconsistency.

${ }^{15} \mathrm{I}$ am indebted to Dan and Jing Jing for sharing their writing and their ideas with me, and to Niki Turnipseed, Antonio Byrd, and Jordan Hayes, along with the reviewers, for their generative and generous comments. Lastly, enough thanks cannot go to Paul Prior, Katherine Flowers, Sandra Tarabochia, Zak Lancaster, and Jonathan Lippman for their feedback on versions of this article. 


\section{WORKS CITED}

Agha, Asif. Language and Social Relations. Cambridge UP, 2007.

Anson, Chris M. "Black Holes: Writing Across the Curriculum, Assessment, and the Gravitational Invisibility of Race." Race and Writing Assessment, edited by Asao B. Inoue and Mya Poe, Peter Lang, 2012, pp. 15-28.

---. "The Pop Warner Chronicles: A Case Study in Contextual Adaptation and the Transfer of Writing Ability." College Composition and Communication, vol. 67, no. 4, 2016, pp. 518-49.

Babel, Anna M., editor. Awareness and Control in Sociolinguistic Research. Cambridge UP, 2016.

Berkenkotter, Carol. "Decisions and Revisions: The Planning Strategies of a Publishing Writer." College Composition and Communication, vol. 34, no. 2, 1983, pp. 156-69.

Bou Ayash, Nancy. "Conditions of (Im)Possibility: Postmonolingual Language Representations in Academic Literacies." College English, vol. 78, no. 6, 2016, pp. 555-77.

Boughey, Chrissie. “Naming' Students' Problems: An Analysis of Language-Related Discourses at a South African University." Teaching in Higher Education, vol. 7, no. 3, 2002, pp. 295-307.

Calvet, Louis-Jean. Towards an Ecology of World Languages. Translated by Andrew Brown, Polity, 2006.

Camps, Anna Mundó, and Marta Milian. "Metalinguistic Activity in Learning to Write: An Introduction." Metalinguistic Activity in Learning to Write, edited by Anna Mundó Camps and Marta Milian, Amsterdam UP, 2000, pp. 1-28.

Chabris, Christopher F., and Daniel J. Simons. The Invisible Gorilla: And Other Ways Our Intuitions Deceive Us. Crown, 2010.

Cox, Michelle, Jeffrey R. Galin, and Dan Melzer. Sustainable WAC: A Whole Systems Approach to Launching and Developing Writing Across the Curriculum Programs. National Council of Teachers of English, 2018.

Donahue, Christiane. “Transfer, Portability, Generalization: (How) Does Composition Expertise 'Carry'?” Exploring Composition Studies: Sites, Issues and Perspectives, edited by Kelly Ritter and Paul Kei Matsuda, Utah State UP, 2012, pp. 145-66.

Edley, Nigel. "Analysing Masculinity: Interpretative Repertoires, Ideological Dilemmas and Subject Positions." Discourse as Data: A Guide for Analysis, edited by Margaret Wetherell, Stephanie Taylor, and Simeon J. Yates, SAGE, 2001, pp. 189-228.

Flash, Pamela. "From Apprised to Revised: Faculty in the Disciplines Change What They Never Knew They Knew." A Rhetoric of Reflection, edited by Kathleen Blake Yancey, Utah State UP, 2016, pp. 227-49.

Flores, Nelson. "From Academic Language to Language Architecture: Challenging Raciolinguistic Ideologies in Research and Practice." Theory Into Practice, vol. 59, no. 1, 2020, pp. 22-31.

Flores, Nelson, and Jonathan Rosa. "Undoing Appropriateness: Raciolinguistic Ideologies and Language Diversity in Education.” Harvard Educational Review, vol. 85, no. 2, 2015, pp. 149-71. Gardner, Rod. When Listeners Talk: Response Tokens and Listener Stance. John Benjamins, 2001.

Geisler, Cheryl. Academic Literacy and the Nature of Expertise: Reading, Writing, and Knowing in 
Academic Philosophy. Lawrence Erlbaum Associates, 1994.

Gilbert, G. Nigel, and Michael Mulkay. Opening Pandora's Box: A Sociological Analysis of Scientists' Discourse. Cambridge UP, 1984.

Giltrow, Janet. "Meta-Genre." The Rhetoric and Ideology of Genre: Strategies for Stability and Change, edited by Richard M. Coe, Lorelei Lingard, and Tatiana Teslenko, Hampton P, 2002, pp. 187-205.

Henkin, Joshua. "Why 'Show, Don't Tell' is the Great Lie of Writing Workshops.” Writer's Digest, www. writersdigest.com/editor-blogs/there-are-no-rules/why-show-dont-tell-is-the-great-lie-ofwriting-workshops. Accessed 10 July 2018.

Heritage, John. "A Change-of-State Token and Aspects of its Sequential Placement." Structures of Social Action: Studies in Conversational Analysis, edited by J. Maxwell Atkinson and John Heritage, Cambridge UP, 1984, pp. 299-345.

Hyland, Ken. "Disciplinary Interactions: Metadiscourse in L2 Postgraduate Writing." Journal of Second Language Writing, vol. 13, no. 2, 2004, pp. 133-51.

Inoue, Asao B. Antiracist Writing Assessment Ecologies: Teaching and Assessing Writing for a Socially Just Future. The WAC Clearinghouse; Parlor P, 2015.

---. "Classroom Writing Assessment as an Antiracist Practice: Confronting White Supremacy in the Judgments of Language.” Pedagogy, vol. 19, no. 3, 2019, pp. 373-404.

---. "How Do We Language So People Stop Killing Each Other, or What Do We Do About White Language Supremacy?” College Composition and Communication, vol. 71, no. 2, 2019, pp. 35269.

Kareem, Jamila M. "Sustained Communities for Sustained Learning: Connecting Culturally Sustaining Pedagogy to WAC Learning Outcomes.” Diverse Approaches to Teaching, Learning, and Writing Across the Curriculum: IWAC at 25, edited by Lesley Erin Bartlett, Sandra L. Tarabochia, Andrea R. Olinger, and Margaret J. Marshall. The WAC Clearinghouse; UP of Colorado, 2020, pp. 293-308.

Kells, Michelle Hall. "Writing Across Communities: Deliberation and the Discursive Possibilities of WAC." Reflections: A Journal of Community-Engaged Writing and Rhetoric, vol. 6, no. 1, 2007, pp. 87-108.

Lancaster, Zak. "Using Corpus Results to Guide the Discourse-Based Interview: A Study of One Student's Awareness of Stance in Academic Writing in Philosophy." Journal of Writing Research, vol. 8, no. 1, 2016, pp. 119-48.

Lawes, Rachel. “Marriage: An Analysis of Discourse." British Journal of Social Psychology, vol. 38, no. 1, 1999, pp. 1-20.

Lea, Mary R., and Brian V. Street. "Student Writing in Higher Education: An Academic Literacies Approach." Studies in Higher Education, vol. 23, no. 2, 1998, pp. 157-72.

Lewis, Mark C. "A Critique of the Principle of Error Correction as a Theory of Social Change." Language in Society, vol. 47, no. 3, 2018, pp. 325-46.

Lindenman, Heather, Martin Camper, Lindsay Dunne Jacoby, and Jessica Enoch. "Revision and Reflection: A Study of (Dis)connections Between Writing Knowledge and Writing Practice." College Composition and Communication, vol. 69, no. 4, 2018, pp. 581-611. 
McCloskey, Rose. “A Guide to Discourse Analysis." Nurse Researcher, vol. 16, no. 1, 2008, pp. 24-44.

Nowacek, Rebecca S. Agents of Integration: Understanding Transfer as a Rhetorical Act. Southern Illinois UP, 2011.

Odell, Lee, Dixie Goswami, and Anne Herrington. “The Discourse-Based Interview: A Procedure for Exploring Tacit Knowledge of Writers in Nonacademic Settings." Research on Writing: Principles and Methods, edited by Peter Mosenthal, Lynn Tamor, and Sean A. Walmsley, Longman, 1983, pp. 220-36.

Olinger, Andrea R. "On the Instability of Disciplinary Style: Common and Conflicting Metaphors and Practices in Text, Talk, and Gesture." Research in the Teaching of English, vol. 48, no. 4, 2014, pp. 453-78.

---. "A Sociocultural Approach to Style." Rhetoric Review, vol. 35, no. 2, 2016, pp. 121-34.

---. "Visual Embodied Actions in Interview-Based Writing Research: A Methodological Argument for Video.” Written Communication, vol. 37, no. 2, 2020, pp. 167-207.

Olson, David. "From Utterance to Text: The Bias of Language in Speech and Writing." Harvard Educational Review, vol. 47, no. 3, 1977, pp. 257-81.

Perryman-Clark, Staci M., and Collin Lamont Craig. "Black Student Success Models: Institutional Profiles of Writing Programs." Black Perspectives in Writing Program Administration: From the Margins to the Center, edited by Staci M. Perryman-Clark and Collin Lamont Craig, National Council of Teachers of English, 2019, pp. 101-14.

Pinker, Steven. "Why Academics Stink at Writing." The Chronicle of Higher Education, 26 Sept. 2014, www.chronicle.com/article/Why-Academics-Writing-Stinks/148989/. Accessed 4 July 2017.

Poe, Mya. "Re-Framing Race in Teaching Writing Across the Curriculum." Anti-Racist Activism: Teaching Rhetoric and Writing, special issue of Across the Disciplines, vol. 10, no. 3, 2013, wac. colostate.edu/docs/atd/race/poe.pdf. Accessed 4 December 2020.

Potter, Jonathan, and Alexa Hepburn. "Eight Challenges for Interview Researchers." The SAGE Handbook of Interview Research: The Complexity of the Craft, edited by Jaber F. Gubrium and James A. Holstein, 2nd ed., SAGE, 2012, pp. 555-70.

Potter, Jonathan, and Michael J. Mulkay. “Scientists' Interview Talk: Interviews as a Technique for Revealing Participants' Interpretative Practices." The Research Interview: Uses and Approaches, edited by Michael Brenner, Jennifer Brown, and David Canter, Academic P, 1985, pp. 247-71.

Preston, Dennis R. "Whaddayaknow?: The Modes of Folk Linguistic Awareness." Language Awareness, vol. 5. no. 1, 1996, pp. 40-74.

Prior, Paul A. “Tracing Process: How Texts Come Into Being." What Writing Does and How It Does It, edited by Charles Bazerman and Paul Prior, Lawrence Erlbaum Associates, 2004, pp. 167-200.

---. Writing/Disciplinarity: A Sociohistoric Account of Literate Activity in the Academy. Lawrence Erlbaum Associates, 1998.

Rosa, Jonathan, and Nelson Flores. "Unsettling Race and Language: Toward a Raciolinguistic Perspective." Language in Society, vol. 46, no. 5, 2017, pp. 621-47.

Rose, Mike. "The Language of Exclusion: Writing Instruction at the University." College English, vol. 47, no. 4, 1985, pp. 341-59.

Sacks, Harvey, Emmanuel A. Schegloff, and Gail Jefferson. "A Simplest Systematics for the 
Organization of Turn-Taking for Conversation." Language, vol. 50, no. 4.1, 1974, pp. 696-735.

Schimel, Joshua. Writing Science: How to Write Papers That Get Cited and Proposals That Get Funded. Oxford UP, 2012.

Silverstein, Michael. “The Limits of Awareness." Sociolinguistic Working Paper No. 84. Southwest Educational Development Laboratory. Reprinted in Linguistic Anthropology: A Reader, edited by Alessandro Duranti, Wiley-Blackwell Publishers, 2001, pp. 382-401.

Simons, Daniel J. “The Demographics of Surveys: Phone vs. Mechanical Turk.” 2012, blog.dansimons. com/2012/12/the-demographics-of-surveys-phone-vs.html. Accessed 10 July 2020.

---. "Writing and Revising." Website, www.dansimons.com/resources/writing_tips.html. Accessed 3 December 2020.

Sprat, Thomas. The History of the Royal Society (Selections), edited by Jack Lynch, www.jacklynch.net/ Texts/sprat.html. Accessed 10 July 2020.

Starke-Meyerring, Doreen. "The Paradox of Writing in Doctoral Education: Student Experiences." Doctoral Education: Research-Based Strategies for Doctoral Students, Supervisors and Administrators, edited by Lynn McAlpine and Cheryl Amundsen, Springer, 2011, pp. 75-95. Street, Brian V. Literacy in Theory and Practice. Cambridge UP, 1984.

Sword, Helen. Stylish Academic Writing. Harvard UP, 2012.

Talja, Sanna. “Analyzing Qualitative Interview Data: The Discourse Analytic Method.” Library \& Information Science Research, vol. 21, no. 4, 1999, pp. 459-77.

Thaiss, Christopher, and Terry Myers Zawacki. Engaged Writers, Dynamic Disciplines: Research on the Academic Writing Life. Boynton/Cook Heinemann, 2006.

Tileagă, Cristian, and Elizabeth Stokoe. "Introduction: The Evolution of Discursive Psychology: From Classic to Contemporary Themes." Discursive Psychology: Classic and Contemporary Issues, edited by Cristian Tileagă and Elizabeth Stokoe, Routledge, 2016, pp. 1-11.

Verschueren, Jef. Ideology in Language Use: Pragmatic Guidelines for Empirical Research. Cambridge UP, 2012.

Walters, Frank D. "Scientific Method and Prose Style in the Early Royal Society." Journal of Technical Writing and Communication, vol. 23, no. 3, 1993, pp. 239-58.

Wetherell, Margaret, and Jonathan Potter. "Discourse Analysis and the Identification of Interpretative Repertoires." Analysing Everyday Explanation: A Casebook of Methods, edited by Charles Antaki, SAGE, 1988, pp. 168-83.

Wiggins, Sally. Discursive Psychology: Theory, Method and Applications. SAGE, 2017.

Wilder, Laura. Rhetorical Strategies and Genre Conventions in Literary Studies: Teaching and Writing in the Disciplines. Southern Illinois UP, 2012.

Wilkinson, Sue, and Celia Kitzinger. "Surprise As an Interactional Achievement: Reaction Tokens in Conversation.” Social Psychology Quarterly, vol. 69, no. 2, 2006, pp. 150-82.

Williams-Farrier, Bonnie J. “'Talkin’ bout Good \& Bad’ Pedagogies: Code-Switching vs. Comparative Rhetorical Approaches." College Composition and Communication, vol. 69, no. 2, 2017, pp. 230 59.

Wingate, Ursula. "Approaches to Academic Literacy Instruction: Classifications, Conflicts and New 
Directions." Re-Theorizing Literacy Practices: Complex Social and Cultural Contexts, edited by David Bloome, Maria Lucia Castanheira, Constant Leung, and Jennifer Rowsell, Routledge, 2019, pp. 182-93.

Young, Vershawn Ashanti. “'Nah, We Straight': An Argument Against Code Switching.” JAC: Journal of Advanced Composition, vol. 29, no. 1/2, 2009, pp. 49-76. 